\title{
The healthiness of Cirsium arvense (L.) Scop. at selected meadow agrocenoses
}

\author{
Zdrowotność Cirsium arvense (L.) Scop. w wybranych \\ agrocenozach łąkowych
}

\author{
Henryk Ratajkiewicz¹, Maria Werner², Zbigniew Karolewski², Roman Kierzek ${ }^{3}$
}

\section{Summary}

The investigations were carried within the meadow agrocenoses, located in the valley of the Warta Landscape Park, between Dolany and Ląd. Different disease symptoms occurring on plant organs of Cirsium arvense such as leaves, shoots and roots were recorded. Dying of inflorescences and infructescences and sometimes dying of the whole plant, as well as damages caused by pests were also observed. Alternaria spp., Epicoccum spp. and Fusarium spp. were the most isolated species from spots, shoots and infructesences. Coniothyrium and Epicoccum were also often isolated from leaves while Acremonium, Phomopsis, Phoma and Sclerotinia sclerotiorum were cultured from the basis of shoots and roots. It was determined that plants of $C$. arvense were sick on all observed sites, however disease severity depended on location and age of the plants. Lower pathogen infections of $C$. arvense were detected within populations with majority of young plants. In July and August powdery mildew (Oidium spp.) and rust (Puccinia punctiformis) were dominating on them, while in the older populations leaf spot diseases and dying of inflorescences and infructescences were observed. Pathogens of $C$. arvense were considered as potential active substances of bioherbicides.

Key words: Cirsium arvense; pathogenic fungi; bioherbicide; meadow agrocenosis

\section{Streszczenie}

Badania wykonano w latach 2011 i 2012 na obszarze agrocenoz łąkowych położonych w dolinie Warty, na terenie Nadwarciańskiego Parku Krajobrazowego pomiędzy Dolanami i Lądem. Zaobserwowano, że na ostrożeniu polnym (Cirsium arvense) występują objawy chorobowe o różnym charakterze na wszystkich organach roślin: liściach, pędach i korzeniach, jak również zamieranie kwiatostanów i owocostanów, czasem całych roślin, a także uszkodzenia spowodowane przez szkodniki. Z plam na liściach, pędach i owocostanach badanych roślin izolowano najczęściej grzyby rodzajów: Alternaria, Epicoccum i Fusarium. Z liści izolowano też często grzyby rodzaju Coniothyrium, a z podstawy pędu i korzeni: Acremonium, Phomopsis, Phoma oraz Sclerotinia sclerotiorum. Stwierdzono, że rośliny $C$. arvense chorowały na wszystkich obserwowanych stanowiskach, nasilenie porażenia zależało jednak od ich lokalizacji i wieku roślin. W populacjach, w których więcej było roślin młodych, zanotowano niższe porażenie $C$. arvense przez patogeny. W lipcu i sierpniu dominował na nich mączniak prawdziwy (Oidium spp.) i rdza ostrożenia (Puccinia punctiformis), natomiast na starszych roślinach plamistość liści oraz zamieranie kwiatostanów i owocostanów. Oceniono znaczenie patogenów ostrożenia polnego jako substancji czynnych potencjalnych bioherbicydów.

Słowa kluczowe: Cirsium arvense; grzyby patogeniczne; bioherbicyd; agrocenoza łąkowa

\author{
Uniwersytet Przyrodniczy w Poznaniu \\ Dąbrowskiego 159, 60-594 Poznań \\ ${ }^{1}$ Katedra Entomologii i Ochrony Środowiska \\ ratajh@up.poznan.pl \\ ${ }^{2}$ Katedra Fitopatologii i Nasiennictwa \\ mwerner@up.poznan.pl; karolew@up.poznan.pl \\ ${ }^{3}$ Instytut Ochrony Roślin - Państwowy Instytut Badawczy \\ Zakład Herbologii i Techniki Ochrony Roślin \\ Władysława Węgorka 20, 60-318 Poznań \\ r.kierzek@iorpib.poznan.pl
}




\section{Wstęp / Introduction}

Ocena zdrowotności i wyodrębnienie patogenów powodujących choroby ostrożenia polnego (Cirsium arvense) jest pierwszym krokiem w kierunku uzyskania izolatów grzybów, które byłyby rozpatrywane jako potencjalne mikoherbicydy. Analizując dane z literatury można zauważyć, że w przypadku zarejestrowanych i stosowanych w wielu rejonach świata bioherbicydów wykorzystano różne gatunki grzybów, które wobec zwalczanej niepożądanej rośliny były ważnymi patogenami i z tego powodu gwarantowały wysoką skuteczność działania (Hyaes 2005; Trujillo 2005; Den Breeÿen i Charudattan 2009).

Celem pracy była ocena występowania i zdrowotności C. arvense na wybranych stanowiskach oraz wyodrębnienie sprawców chorób powodujących objawy chorobowe o istotnym znaczeniu dla wzrostu i rozwoju tego chwastu.

\section{Materiały i metody / Materials and methods}

Obserwacje prowadzono od maja do października w latach 2011 i 2012 w województwie wielkopolskim, na terenie Nadwarciańskiego Parku Krajobrazowego, pomiędzy

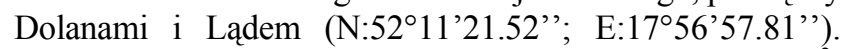
Wybrano 7 stanowisk o powierzchniach od 200 do $800 \mathrm{~m}^{2}$ : łąka koszona (stanowisko 1), łąki niekoszone lub koszone bardzo rzadko $(2,7)$, łąka zniszczona przez powódź w 2010 r. z naniesionymi łachami piasku (6), przydroże oraz skarpa na skraju łąk i pól uprawnych (3) oraz dwa odłogi położone na wyniesionym brzegu pradoliny Warty $(4,5)$.

Na stanowiskach 2., 3., 6. i 7. wydzielono podrzędne obszary w liczbie i oznaczeniach przedstawionych w tabeli 1. Wydzielone w obrębie stanowisk obszary różniły się nieco warunkami i porastającą je roślinnością. Wyróżnione w obrębie stanowiska 2. lokalizacje 2a i 2d usytuowane były przy lesie. Obszar 3. obejmował skarpę (3b) oraz przydroże, gdzie pozostawiono liczne murszejące gałęzie po cięciu topoli (3a). Na stanowisku 6. oceniono zdrowotność roślin rosnących na obrzeżu piaszczystych łach $(6 \mathrm{a}, \mathrm{b}, \mathrm{c})$. Koszenie na stanowisku 1. przeprowadzono dwukrotnie każdego roku (2011 i 2012), łąki na stanowiskach 2. i 7. nie były koszone w ostatnich pięciu latach, z wyjątkiem obszaru 7a, gdzie rośliny skoszono na części stanowiska jednorazowo i tylko we wrześniu $2011 \mathrm{r}$.

Liczebność ostrożenia polnego na ocenianych stanowiskach określono zgodnie z normą EPPO PP 1/61 (2009) $\mathrm{w}$ jednym terminie - pierwszej dekadzie września. Zdrowotność $C$. arvense oceniano w 3 terminach: lipcu, sierpniu i wrześniu w obu latach badań; w tym czasie zbierano też rośliny $\mathrm{z}$ objawami chorobowymi do badań laboratoryjnych.

Izolacje wykonywano z liści, łodyg, kwiatostanów i korzeni roślin. Materiał odkażano w $1 \%$ podchlorynie sodu, wycinano tkankę na granicy miejsc $\mathrm{z}$ widocznymi objawami, a następnie wykładano na pożywkę Potato Dextrose Agar (PDA; Sigma Aldrich). Opisano cechy makro- i mikroskopowe kultur i oznaczono grzyby według kluczy (Barnet i Hunter 1972; Majewski 1979; Sałata 1985; Kwaśna i wsp. 1991; Chełkowski i Visconti 1992).

$\mathrm{Na}$ nadziemnych częściach roślin, nasilenie występowania objawów chorobowych oraz spowodowanych przez inne czynniki oceniano losowo w 5 wybranych punktach na każdym stanowisku, wybierając 5 roślin zlokalizowanych w obrębie miejsca obserwacji.

Porażenie roślin przez patogeny oceniono na liściach, łodygach i owocostanach. Na liściach wyróżniono objawy plamistości, nekroz oraz mączniaka prawdziwego i rdzy ostrożenia. Występowanie plamistości oraz mączniaka prawdziwego oceniano według własnej, 6-stopniowej skali wyrażającej powierzchnię objętą widocznymi objawami: 0 - liście zdrowe; 1 - porażenie do $1 \% ; 2$ - porażenie $1-5 \% ; 3-6-20 \% ; 4-21-60 \% ; 5$ - powyżej $60 \%$. W przypadku rdzy szacowano występowanie oznak etiologicznych (uredinia i telia). Oceniono 5 liści wybranych ze środkowej części każdej rośliny według skali: 0 - brak porażenia; 1 - od 1 do 2 urediniów na ocenianych liściach; 2 - od 3 do 9 urediniów na ocenianych liściach; 3 - od 10 do 20 urediniów na jednym liściu; 4 - od 11 do 50 urediniów na jednym liściu; 5 - powyżej 50 urediniów na jednym liściu aż do zamierania rośliny z powodu rdzy.

$\mathrm{Na}$ liściach oceniono oddzielnie obszar nekroz oraz uszkodzeń przez szkodniki. Na łodydze określono obszar zamierania tkanki i chloroz. Począwszy od pełni owocowania za owocostan porażony uznawano taki, który nie wytworzył puchu kielichowego i utracił naturalną barwę. Powierzchnię objętą przez nekrozy na liściach, łodydze i udział zamierających owocostanów w ich ogólnej liczbie oszacowano według 6-stopniowej skali dotyczącej plamistości. Na podstawie danych liczbowych obliczono procent porażenia roślin według wzoru TownsendaHeubergera (Püntener 1981). Na podstawie tego samego wzoru obliczono procent porażenia organów roślin dotyczący tkanek objętych nekrozą i uszkodzonych przez szkodniki.

Uszkodzenia rośliny przez szkodniki o aparacie gębowym ssącym i gryzącym oceniano według skali użytej do oceny występowania plamistości; tylko w przypadku szkodników powodujących powstanie galasów na łodygach podawano bezwzględną liczbę zniekształceń na łodydze.

\section{Wyniki i dyskusja / Results and discussion}

W roku 2011, wybór stanowisk ostrożenia polnego na łąkach Doliny Warty był trudny ze względu na długotrwałą powódź w okresie wiosenno-letnim 2010 r. Spośród blisko 20 wcześniej obserwowanych obszarów (Ratajkiewicz i wsp. 2010), niemal wszystkie zostały zupełnie zniszczone. Stanowiska te były położone na rozległym dnie doliny Warty, zwykle zalewanym podczas wczesnowiosennego przyboru wody, który jednak nie niszczył łąk i nie ograniczał populacji C. arvense. Powódź z 2010 roku poczyniła znaczne szkody i $\mathrm{z}$ tego powodu do badań zakwalifikowano jedynie stanowisko 1. ze szczątkową populacją ostrożenia polnego. Najlepiej przetrwały populacje ostrożenia polnego, które zajmowały niewielkie 
wyniesienia w dolinie (stanowiska 2a, 2d, 7a, 7b) i jej obrzeża (3a, 3b), a także położone na koronie koryta Warty, z których nawet podczas powodzi epizodycznych woda szybko ustępuje. Specyficzne warunki wzrostu ostrożenia polnego były na stanowisku 6., położonym obok koryta Warty. Łąka została zdewastowana przez powódź w 2010 r. na skutek zasypania jej części grubą warstwą piasku rzecznego $(30-70 \mathrm{~cm})$, ułożonego po zalewie

Tabela 1. Porażenie C. arvense przez patogeny i uszkodzenia przez szkodniki na wybranych stanowiskach (wrzesień 2011 i 2012)

Table 1. The damages of $C$. arvense caused by pathogens and pests on selected locations (September 2011 and 2012)

\begin{tabular}{|c|c|c|c|c|c|c|c|c|c|}
\hline \multirow{4}{*}{$\begin{array}{c}\text { Stanowisko } \\
\text { Location }\end{array}$} & \multicolumn{6}{|c|}{ Liście - Leaves } & \multirow{3}{*}{$\begin{array}{c}\text { Lodyga } \\
\text { Stem }\end{array}$} & \multirow{3}{*}{$\begin{array}{c}\text { Owocostan } \\
\text { Infructescence }\end{array}$} & \multirow{4}{*}{$\begin{array}{l}\text { Uszkodzenia } \\
\text { rośliny } \\
\text { ogółem** } \\
\text { Total damages } \\
\text { of plant }\end{array}$} \\
\hline & \multicolumn{3}{|c|}{$\begin{array}{l}\text { objawy chorób } \\
\text { disease symtoms }\end{array}$} & \multicolumn{2}{|c|}{$\begin{array}{c}\text { uszkodzenia } \\
\text { przez szkodniki } \\
\text { damages by pests }\end{array}$} & \multirow{2}{*}{$\begin{array}{l}\text { zamieranie } \\
\text { ogółem } \\
\text { dying } \\
\text { total }\end{array}$} & & & \\
\hline & $\begin{array}{l}\text { plamistości } \\
\text { spots }\end{array}$ & $\begin{array}{c}\text { mączniak } \\
\text { prawdziwy } \\
\text { powdery mildew }\end{array}$ & $\begin{array}{l}\text { rdza ostrożenia } \\
\text { rust of Canada } \\
\text { thistle }\end{array}$ & $\begin{array}{l}\text { gryzące } \\
\text { chewing }\end{array}$ & $\begin{array}{c}\text { ssące } \\
\text { sucking }\end{array}$ & & & & \\
\hline & \multicolumn{8}{|c|}{ procent porażenia i uszkodzenia - infestation and damage index [\%] } & \\
\hline \multicolumn{10}{|c|}{2011} \\
\hline 1 & 0 & 0 & 0 & 0,8 & 1,1 & 1,2 & 0 & - & 0,06 \\
\hline $2 \mathrm{a}$ & 36,8 & 0 & 0 & 17,6 & 16,0 & 48,8 & 12,0 & 36,0 & 2,8 \\
\hline $2 d$ & 45,6 & 0 & 21,6 & 5,6 & 3,2 & 71,2 & 9,6 & 43,2 & 3,8 \\
\hline $3 a$ & 60,8 & 0 & 0 & 30,4 & 0,8 & 88,0 & 56,0 & 25,2 & 4,5 \\
\hline $3 b$ & 32,8 & 0 & 33,6 & 26,4 & 3,2 & 96,0 & 85,6 & 28,8 & 4,9 \\
\hline 4 & 45,6 & 0 & 28,0 & 8,8 & 21,6 & 92,8 & 70,4 & 27,2 & 4,8 \\
\hline 5 & 38,4 & 0 & 45,6 & 14,4 & 16,8 & 84,8 & 72,0 & 34,4 & 4,4 \\
\hline $6 a$ & 5,6 & 91,2 & 12,0 & 4,8 & 3,2 & 90,4 & 90,4 & 34,8 & 4,7 \\
\hline $6 b$ & 29,6 & 48,8 & 45,6 & 12,0 & 4,8 & 68,8 & 62,4 & 25,6 & 3,6 \\
\hline $6 c$ & 6,4 & 14,4 & 39,2 & 14,4 & 9,6 & 51,2 & 40,8 & 26,0 & 2,8 \\
\hline $7 \mathrm{a}$ & 49,2 & 0 & 2,8 & 21,6 & 20,4 & 58,4 & 32,0 & 26,8 & 3,9 \\
\hline $7 b$ & 47,2 & 0 & 14,4 & 11,2 & 18,4 & 80,0 & 52,8 & 89,2 & 4,2 \\
\hline \multicolumn{10}{|c|}{2012} \\
\hline 1 & 0 & 0 & 0 & 1,2 & 1,9 & 3,3 & 0 & - & - \\
\hline $2 a$ & 73,6 & 0 & 0 & 13,6 & 45,6 & 84,0 & 53,6 & 78,8 & 4,3 \\
\hline $2 d$ & 88,8 & 0 & 11,2 & 7,2 & 44,0 & 99,6 & 53,6 & 93,2 & 4,7 \\
\hline $3 a$ & 95,2 & 0 & 0 & 21,6 & 40,0 & 98,4 & 75,2 & 92,4 & 4,9 \\
\hline $3 b$ & 97,6 & 0 & 28,8 & 20,0 & 26,4 & 99,2 & 93,6 & 98,4 & 4,9 \\
\hline 4 & 88,8 & 0 & 1,6 & 24,4 & 10,4 & 96,0 & 80,0 & 100 & 4,9 \\
\hline 5 & 62,0 & 0 & 37,6 & 20,8 & 26,4 & 92,8 & 70,4 & 98,8 & 4,7 \\
\hline $6 a$ & $19,2^{*}$ & $100^{*}$ & $4,0^{*}$ & 6,4 & 10,4 & 100 & 100 & 98,0 & 5,0 \\
\hline $6 \mathrm{~b}$ & $11,2^{*}$ & $100^{*}$ & $12,8^{*}$ & 10,4 & 4,8 & 100 & 100 & 100 & 5,0 \\
\hline $6 c$ & $31,2 *$ & $97,6^{*}$ & $1,6^{*}$ & 12,8 & 11,2 & 100 & 96,0 & 97,2 & 5,0 \\
\hline $7 \mathrm{a}$ & 80,0 & 0 & 0 & 4,8 & 38,4 & 88,0 & 51,2 & 95,6 & 4,4 \\
\hline $7 b$ & 96,0 & 0 & 0 & 4,8 & 34,4 & 99,2 & 72,8 & 99,2 & 4,9 \\
\hline
\end{tabular}

*w 2012 r. wyniki podano dla 14 sierpnia - in 2012 results were given for 14 August

**oceniono 30 września według skali - assessment done on 30 September using the scale:

0 - zdrowe - healthy

1 - rośliny zniszczone (liście, łodygi) do $25 \%$ - plants destroyed (leaves, stems) up to $25 \%$

$2-26$ do - to 50

$3-51$ do - to 70

$4-71$ do - to 90

5 - powyżej $90 \%$ - above $90 \%$ 
Tabela 2. Grzyby chorobotwórcze wyizolowane z wykazujących zmiany chorobowe roślin C. arvense

Table 2. Pathogenic fungi derived from $C$. arvense with disease symptoms

\begin{tabular}{|c|c|c|c|}
\hline $\begin{array}{l}\text { Objawy chorobowe } \\
\text { Disease symptoms }\end{array}$ & $\begin{array}{l}\text { Grzyby (rodzaje) } \\
\text { Genus of fungi }\end{array}$ & $\begin{array}{l}\text { Termin izolacji } \\
\text { lub obserwacji } \\
\text { Term of isolation } \\
\text { or observation }\end{array}$ & Stanowisko - Location \\
\hline \multicolumn{4}{|c|}{ Liść - Leaf } \\
\hline $\begin{array}{l}\text { Drobne plamy szarobrązowe } \\
\text { lub czarne } \\
\text { Small gray-brown or black } \\
\text { spots }\end{array}$ & \begin{tabular}{|l|} 
Alternaria \\
Fusarium \\
Sphaeropsis \\
Epicoccum \\
\end{tabular} & $\begin{array}{l}\text { I, II, III } \\
\text { II } \\
\text { III } \\
\text { I, II, III }\end{array}$ & $\begin{array}{l}2 \mathrm{~d}, 3 \mathrm{a}, 4,5,7 \mathrm{a} \\
4 \\
6 \mathrm{c} \\
2 \mathrm{a}, 2 \mathrm{a}, 2 \mathrm{~d}, 3 \mathrm{a}, 3 \mathrm{~b}, 5,6 \mathrm{c}, 7 \mathrm{a}, 7 \mathrm{~b}\end{array}$ \\
\hline $\begin{array}{l}\text { Plamy ciemnobrązowe } \\
\text { zlewające się } \\
\text { Confluent dark spots }\end{array}$ & \begin{tabular}{|l|} 
Alternaria \\
Colletotrichum \\
Fusarium \\
Helminthosporium
\end{tabular} & $\begin{array}{l}\text { I, II,III } \\
\text { I } \\
\text { II } \\
\text { I }\end{array}$ & $\begin{array}{l}2 \mathrm{a}, 3 \mathrm{a}, 4,5,6 \mathrm{~b}, 6 \mathrm{c} \\
3 \mathrm{a} \\
3 \mathrm{a}, 3 \mathrm{~b}, 5 \\
3 \mathrm{a},\end{array}$ \\
\hline $\begin{array}{l}\text { Plamy dwubarwne, drobne i } \\
\text { większe o średnicy } 2-4 \mathrm{~cm} \\
\text { Bi-color spots, small } \\
\text { and bigger with a diameter } \\
\text { of } 2-4 \mathrm{~cm}\end{array}$ & $\begin{array}{l}\text { Alternaria } \\
\text { Fusarium }\end{array}$ & $\begin{array}{l}\text { I, II, III } \\
\text { I, II }\end{array}$ & $\begin{array}{l}2 \mathrm{a}, 3 \mathrm{~b}, 6 \mathrm{c}, 7 \mathrm{a} \\
2 \mathrm{a}, 3 \mathrm{~b}, 7 \mathrm{a}\end{array}$ \\
\hline $\begin{array}{l}\text { Mączniak prawdziwy } \\
\text { Powdery mildew }\end{array}$ & Oidium & II, III & $6 \mathrm{a}, 6 \mathrm{~b}, 6 \mathrm{c}$ \\
\hline $\begin{array}{l}\text { Rdza ostrożenia } \\
\text { Rust of Canada thistle }\end{array}$ & Puccinia (P. punctiformis) & I, II, III & $2 \mathrm{~d}, 3 \mathrm{ab}, 4,5,6 \mathrm{abc}, 7 \mathrm{ab}$ \\
\hline \multicolumn{4}{|c|}{ Łodyga - Stem } \\
\hline $\begin{array}{l}\text { Plamy brunatne, nekroza } \\
\text { wnętrza pędu } \\
\text { Brown spots, necrosis inside } \\
\text { of stem }\end{array}$ & $\begin{array}{l}\text { Alternaria } \\
\text { Fusarium } \\
\text { Phomopsis } \\
\text { Epicoccum } \\
\end{array}$ & $\begin{array}{l}\text { I, II, III } \\
\text { I, } \\
\text { I } \\
\text { I, III }\end{array}$ & $\begin{array}{l}2 \mathrm{a}, 2 \mathrm{~d}, 3 \mathrm{a} \\
2 \mathrm{a}, 2 \mathrm{~d}, 7 \mathrm{a} \\
2 \mathrm{a}, 2 \mathrm{~d} \\
2 \mathrm{~b}, 2 \mathrm{~d}, 3 \mathrm{a}, 3 \mathrm{~b}, 5,6 \mathrm{c}, 7 \mathrm{a}, 7 \mathrm{~b}\end{array}$ \\
\hline $\begin{array}{l}\text { Mączniak prawdziwy } \\
\text { Powdery mildew }\end{array}$ & Oidium & II, III & $6 \mathrm{a}, 6 \mathrm{~b}, 6 \mathrm{c}$ \\
\hline $\begin{array}{l}\text { Rdza ostrożenia } \\
\text { Rust of Canada thistle }\end{array}$ & Puccinia (P. punctiformis) & I, II, III & $2 \mathrm{~d}, 3 \mathrm{ab}, 4,5,6 \mathrm{abc}, 7 \mathrm{ab}$ \\
\hline \multicolumn{4}{|c|}{ Podstawa pędu - Basis of shoot } \\
\hline $\begin{array}{l}\text { Plamy } \\
\text { Spots }\end{array}$ & \begin{tabular}{|l} 
Alternaria \\
Phomopsis \\
Helminthosporium \\
Acremonium \\
Sclerotinia \\
\end{tabular} & $\begin{array}{l}\text { I } \\
\text { I } \\
\text { I } \\
\text { I } \\
\text { I }\end{array}$ & $\begin{array}{l}6 \mathrm{a}, 6 \mathrm{~b} \\
6 \mathrm{a}, 6 \mathrm{~b} \\
6 \mathrm{a} \\
2 \mathrm{ad}, 6 \mathrm{a} \\
1\end{array}$ \\
\hline \multicolumn{4}{|c|}{ Kwiatostan/owocostan - Inflorescence/infructescence } \\
\hline $\begin{array}{l}\text { Brunatna szypułka } \\
\text { Brown peduncle }\end{array}$ & $\begin{array}{l}\text { Alternaria } \\
\text { Fusarium } \\
\text { Phomopsis }\end{array}$ & $\begin{array}{l}\text { I, II, III } \\
\text { II } \\
\text { II }\end{array}$ & $\begin{array}{l}2 a, 5,6 b, 7 b \\
2 a, 7 b \\
5\end{array}$ \\
\hline \multicolumn{4}{|c|}{ Korzenie - Roots } \\
\hline $\begin{array}{l}\text { Brunatne plamy, } \\
\text { zamieranie rośliny } \\
\text { Brown spots, dying of plant }\end{array}$ & $\begin{array}{l}\text { Phomopsis } \\
\text { Phoma } \\
\text { Acremonium } \\
\text { Fusarium } \\
\text { Sclerotinia }\end{array}$ & $\begin{array}{l}\text { II } \\
\text { III } \\
\text { I, III } \\
\text { III } \\
\text { I }\end{array}$ & $\begin{array}{l}2 \mathrm{~d} \\
2 \mathrm{~d} \\
2 \mathrm{ad}, 6 \mathrm{a} \\
2 \mathrm{a}, 2 \mathrm{~d}, 3 \mathrm{~b} \\
1\end{array}$ \\
\hline
\end{tabular}

w łachach. Zwykle na ich obrzeżu lub w miejscach o mniejszej grubości warstwy piasku, powstały nowe kolonie ostrożenia polnego, być może na skutek przemieszczenia fragmentów korzeni wraz z wodą. Rosnące tam rośliny cechowały się silnym wzrostem i dużym zagęszczeniem pędów, osiagającym już po roku nawet ponad 100 na $1 \mathrm{~m}^{2}$. Podobnie było w 2012 r., średnia liczebność pędów wyniosła na stanowisku $6 \mathrm{a}-35$; $6 \mathrm{~b}-46$; 6c - 67 szt. na $1 \mathrm{~m}^{2}$. Na pozostałych stanowiskach liczebność była mniejsza niż 50 zarówno w 2011, jak i 2012 r. Średnia nie przekraczała 20 pędów na $1 \mathrm{~m}^{2}$. $\mathrm{Na}$ stanowisku 1. ostrożeń nie był liczny, od 0 do 2 osobników na $1 \mathrm{~m}^{2}$, całe stanowisko miało powierzchnię około $20000 \mathrm{~m}^{2}$, a rośliny osiagnęły bardzo małą wysokość, do $30 \mathrm{~cm}$, co wynikało ze skutków powodzi, jak też koszenia łąki. W 2012 r. z wyjątkiem stanowiska 1., 
najmniejszą liczebność ostrożenia polnego stwierdzono na stanowiskach zlokalizowanych na obrzeżu doliny (3a i 3b) oraz na jej wyniesionym brzegu (4 i 5). Wybrane do badań stanowiska były zróżnicowane pod względem usytuowania, liczebności $C$. arvense oraz warunków wzrostu roślin, co mogło wpłynąć na ich kondycję, ale również sprzyjać rozwojowi, bądź ograniczać występowanie chorób i szkodników. Porażenie roślin w różnych lokalizacjach obrazuje tabela 1 .

Porównując zdrowotność $C$. arvense na wybranych do badań stanowiskach można zauważyć, że ostrożeń polny nie był opanowany przez choroby na stanowisku 1. , również nie zaobserwowano rozległych uszkodzeń przez szkodniki (tab. 1). Biorąc pod uwagę usytuowanie obszaru, jak i zniszczenie starej populacji ostrożenia przez powódź, stan ten może wynikać z braku źródeł infekcji. Na tym obszarze, jedynie wiosną 2011 r., stwierdzono występowanie rdzy na bardzo nielicznych osobnikach, które przetrwały powódź; rośliny te jednak wkrótce zamarły. W 2012 r. populacja chwastu była nieliczna, a na rosnących tam roślinach nie stwierdzono objawów chorób. Uszkodzenia spowodowane przez szkodniki obserwowano sporadycznie (tab. 1).

$\mathrm{Na}$ pozostałych stanowiskach, szczególnie w okresie sierpnia i września 2011 r., stwierdzono bardzo silne porażenie roślin przez oceniane patogeny, największe na obszarach 3b, 4 i 6a (tab. 1). W 2012 r. nekrotyczne uszkodzenia roślin były większe na każdym ze stanowisk. Uszkodzenia roślin przez szkodniki były mniejsze niż przez choroby. W obu latach w ostatnim terminie obserwacji (wrzesień), uszkodzenie przez agrofagi ogółem było najwyższe na stanowiskach 3b, 4 i 6a, a w 2012 r. także na innych $-3 \mathrm{a}, 5,6 \mathrm{~b}, 6 \mathrm{c}$ i $7 \mathrm{~b}$.

Rola szkodników w ograniczaniu wzrostu ostrożenia polnego była największa w 2011 r. na stanowisku 7, a w 2012 r. na stanowisku 3a. Szkodniki spowodowały najmniejsze uszkodzenia $\mathrm{w}$ obu latach na łące koszonej (stanowisko 1).

Objawy mączniaka prawdziwego na ostrożeniach zaobserwowano jedynie na stanowisku 6 . (a, b, c). W obu latach badań było ono kolonizowane przez nowe osobniki chwastu, na których pojawiły się również objawy rdzy. Analizując dane $\mathrm{z}$ tabeli 2. można zauważyć, że rdza (P. punctiformis) występowała także na stanowiskach: $2 \mathrm{~d}$, 3a, 3b, 4, 5, 7a, 7b; w tych przypadkach nowe pędy wyrastały z korzeni, które przetrwały zimę i mogły być źródłem infekcji (Ratajkiewicz i wsp. 2009).

$\mathrm{Na}$ liściach, pędach i korzeniach badanych roślin zaobserwowano również inne różnorodne objawy chorobowe. Najczęściej spotykanymi były plamy o różnym wy- glądzie i barwie (tab. 2), obserwowane na wszystkich stanowiskach i powodowane przez grzyby. Do najczęściej izolowanych należały gatunki rodzajów: Alternaria, Epicoccum i Fusarium. Obok nich wyodrębniono też izolaty rodzaju: Acremonium, Colletotrichum, Helminthosporium, Phoma, Phomopsis. Analizując dane z literatury można zauważyć, że spośród grzybów wybieranych do zwalczania chwastów wykorzystywano gatunki należące do rodzaju Alternaria. W zwalczaniu krzewów rodzaju Cassia znalazła zastosowanie A. casiae (Hayes 2005). Nie jest to odosobniony przypadek użycia mikoherbicydu W ograniczaniu niepożądanych roślin (Trujillo 2005; Den Breeÿen i Charudattan 2009). Bioherbicydy oparte na patogenicznych wobec chwastów grzybach różnych gatunków znalazły zastosowanie w zwalczaniu C. arvense, Cyperus esculentus, Aeschynomene virginica, Cuscuta spp., Malva spp. (Bourdôt i wsp. 1993; Hayes 2005). W Nowej Zelandii trwaja prace nad zastosowaniem $S$. sclerotiorum do zwalczania ostrożenia polnego w zbożach oraz jaskra ostrego na pastwiskach (Sekutowski 2010).

Oceniając możliwość wykorzystania grzybów w zwalczaniu $C$. arvense, spośród patogenów wyosobnionych $\mathrm{z}$ tego chwastu, w ramach badań opisanych w niniejszej pracy, najbardziej obiecującymi wydają się być licznie pozyskiwane izolaty rodzajów: Alternaria, Colletotrichum i Epicoccum, a także uszkadzające nie tylko organy nadziemne roślin, ale również korzenie grzyby rodzajów: Fusarium i Sclerotinia.

\section{Wnioski / Conclusions}

1. Ostrożeń polny był uszkadzany w znacznym stopniu przez grzyby porażające liście, pędy, owocostany i korzenie.

2. Wyizolowane z C. arvense grzyby należały do różnych rodzajów: Acremonium, Alternaria, Colletotrichum, Epicoccum, Fusarium, Helminthosporium, Oidium, Phomopsis, Phoma, Puccinia i Sclerotinia.

3. Najliczniej izolowane $\mathrm{z}$ liści $\mathrm{z}$ objawami chorobowymi były gatunki rodzaju Alternaria, natomiast z pędów i korzeni Fusarium i Sclerotinia.

Praca została sfinansowana i wykonana dzięki wsparciu Ministerstwa Nauki i Szkolnictwa Wyższego, projekt nr NN 310307939.

\section{Literatura / References}

Barnett H.L., Hunter B.B. 1972. Illustrated Genera of Imperfect Fungi. Burgess Publishing Company. Minneapolis, 241 pp.

Bourdôt G.W., Harvey I.C., Hurrell G.A., Alexander R.T. 1993. An experimental mycoherbicide utilizing Sclerotinia sclerotiorum controls pasture populations of Cirsium arvense in Canterbury. In: Proc. 46th New Zealand Plant Protection Conference: $251-256$.

Chełkowski J., Visconti A. 1992. Alternaria Biology, Plant Diseases and Metabolites. In Topics in Secondary Metabolism. V. 3. Elsevier Amsterdam-London-New York-Tokyo, 62 pp.

Den Breeÿen A., Charudattan R. 2009. Biological control of invasive weeds in forests and natural areas by using microbial agents. p. 189-209. In: Management of Invasive Weeds. Inderijt ed. Invading Nature, Springer Science + Bussines Media B.V., 364 pp. 
Hayes L. 2005. What is new in biological control of weeds? Manaaki Whenua Landcare Research, Lincoln, New Zealand 34: 1-8.

Kwaśna H., Chełkowski J., Zajkowski P. 1991. Flora Polska. Rośliny zarodnikowe Polski i ziem ościennych. Grzyby (Mycota). T. XXII. PWN, Kraków, 137 ss.

Majewski T. 1979. Flora Polska. Rośliny zarodnikowe Polski i ziem ościennych. Grzyby (Mycota). T. XI. PWN, Warszawa-Kraków, 463 ss.

Norma EPPO PP 1/61(3). 2009. Ocena skuteczności herbicydów. Chwasty na terenach trawiastych.

Püntener W. 1981. Field trial manuale. [Podręcznik doświadczalnictwa polowego w ochronie roślin - tłumaczenie na j. polski Zbigniew Ginter]. Inst. Ochr. Roślin, Poznań, 244 ss.

Ratajkiewicz H., Karolewski Z., Werner M. 2009. Ocena możliwości wykorzystania patogenów ostrożenia polnego [Cirsium arvense (L) Scop.] do biologicznego zwalczania tego chwastu. [Assessment of potential application of Canada thistle (Cirsium arvense) pathogens in biological control of this weed]. Prog. Plant Prot./Post. Ochr. Roślin 49 (2): 879-882.

Ratajkiewicz H., Werner M., Karolewski Z. 2010. Grzyby chorobotwórcze występujące na Cirsium arvense i innych chwastach oraz możliwości ich wykorzystania w ochronie biologicznej. [Pathogenic fungi occurring on Cirsium arvense and other weeds and possibility of using them in biological control]. Prog. Plant Prot./Post. Ochr. Roślin 50 (4): 2008-2012.

Sekutowski T. 2010. Alleloherbicydy i bioherbicydy - mit czy rzeczywistość? J. Res. Appl. Agr. Engng 55 (4): 84-90.

Sałata B. 1985. Flora Polska. Rośliny zarodnikowe Polski i ziem ościennych. Grzyby (Mycota). T. XV. PWN, Warszawa-Kraków, 247 ss.

Trujillo E.E. 2005. History and success of plant pathogens for biological control of introduced weeds in Hawaii. Biol. Control 33: $113-122$. 